\title{
p53 and Regulation of Bioactive Sphingolipids
}

\author{
Linda A. Heffernan-Stroud and Lina M. Obeid \\ Ralph H. Johnson Veterans Affair Medical Center, Charleston, South Carolina, Departments of \\ Medicine and Biochemistry and Molecular Biology, Medical University of South Carolina, \\ Charleston, SC, USA
}

\section{Introduction}

It is becoming increasingly evident in the literature that the sphingolipid metabolizing enzyme sphingosine kinase 1 (SK1) (E.C. 2.7.1.91) may act as an oncogene (Xia et al. 2000),(Pitson et al. 2005; Vadas et al. 2008; Bergelin et al. 2009). Although most studies focus on the activation/upregulation of SK1, we are interested in the novel concept of SK1 downregulation as a mechanism of tumor suppression. Our laboratory has previously shown that SK1 proteolysis is p53-dependent in Molt-4 leukemia cells: inactivation of p53 inhibited SK1 proteolysis after genotoxic stress (Taha et al. 2004). This review expands on this initial observation and is directed at exploring the p53-dependent regulation of sphingolipids and their metabolizing enzymes. Here, we provide background about the tumor suppressor p53 and discuss the currently known points of connection between the p53 and sphingolipid pathways, along with the therapeutic concept of tumor cell senescence.

\section{Tumor Suppressor Protein p53}

Originally identified in its mutant form, p53 is now known to be one of the most commonly mutated tumor suppressor proteins in human cancers. In fact, $50 \%$ of all cancers appear to harbor a mutation in p53 (Vogelstein B 2000; Soussi 2007; Weisz L 2007). In healthy cells, low 553 concentrations are maintained by a negative-feedback loop in which $\mathrm{p} 53$ promotes Mdm2 expression which, in turn, tags p53 for nuclear export and proteasomal degradation (Vogelstein B 2000). When stress signals are recognized by the cell, p53 can accumulate in the nucleus and transcriptionally regulate genes to control the cell's fate. For instance, p53 can induce expression of $\mathrm{p} 21$, a cyclin-dependent kinase inhibitor, which leads to cell cycle arrest (Bates S 1998). p53 can also activate both death-receptor and mitochondrial apoptotic pathways by inducing the expression of various pro-apoptotic genes (Vousden KH 2002). Additionally, cytoplasmic p53 has been shown to induce non-transcriptional tumor suppressor functions (Green and Kroemer 2009), such that overexpression of a mutant p53 that lacks a DNA binding domain can still induce apoptosis in human cells (Haupt et al. 1995; Kakudo et al. 2005).

For apoptotic events, p53 must accumulate in the cell. Several kinases can activate p53 via phosphorylation after DNA damage, and such post-translational modifications can protect p53 from degradation. An alternative path for p53 accumulation is through the induction of p19 ARF, which can inhibit p53's degradation by Mdm2. (Evan G 1998). Such cellular stress causes p53 to accrue within the cell, which signals for apoptosis, growth arrest, and

Publisher's Disclaimer: This is a PDF file of an unedited manuscript that has been accepted for publication. As a service to our customers we are providing this early version of the manuscript. The manuscript will undergo copyediting, typesetting, and review of the resulting proof before it is published in its final citable form. Please note that during the production process errors may be discovered which could affect the content, and all legal disclaimers that apply to the journal pertain. 
cellular senescence to prevent tumorigenesis. As reviewed extensively in various reports, (Kim and Deppert 2007; Strano et al. 2007; Weisz et al. 2007), p53's involvement in tumorigenesis could take one of three forms: (1) complete loss of wild type (WT) p53, leading to loss of the cell's growth-inhibitory response to physiologic or genotoxic stress; (2) a dominant-negative function of mutant p53 such that it can inactivate the tumor suppressive function of WT p53, i.e., inhibiting the formation of tetrameric complexes in cells; and (3) a mutant p53 gain of function such as altered gene expression regulation with oncogenic properties such as chemoresistance conferred by MDR-1, or inhibitory interactions with p53 family members, p63 and p73 (Weisz et al. 2007). For twenty years, the creation of genetically altered mice lacking p53 or expressing mutant p53 has produced animals prone to early carcinogenesis, and has thus illustrated the important tumor suppressive functions of p53 in vivo (Donehower et al. 1992; Jacks et al. 1994; Soussi 2007).

\section{p53 and Ceramide}

Both p53 and ceramide have been shown to regulate cell cycle arrest, senescence, and apoptosis. Early work in our laboratory showed that gamma irradiation induced p53 and led to a p53-dependent increase in ceramide in human leukemia and mouse fibrosarcoma cell lines. However, ceramide was also observed to accumulate irrespective of p53 upregulation in other growth-suppressive pathways (Dbaibo et al. 1998). Later, this p53-dependent ceramide generation was shown to be driven by de novo ceramide synthesis through upregulation of ceramide synthases (CerS), particularly CerS5, leading predominantly to $\mathrm{C}_{16}$-ceramide accumulation (Panjarian et al. 2008). Likewise, several other reports suggest that ceramide accumulation is an important downstream mediator of the p53 response (Kim et al. 2002; El-Assaad et al. 2003; Villani et al. 2006), whereas others have shown that p53 and ceramide are concomitantly upregulated in response to various cell stressors (El-Assaad et al. 2003; Nasr et al. 2005; Villani et al. 2006), and that ceramide can accumulate and signal for apoptosis, irrespective of p53 status (Yang and Duerksen-Hughes 2001; Deng et al. 2009). Beyond apoptosis, ceramide has also been shown to mediate G1 arrest in a p53independent manner through its induction of $\mathrm{p} 21$ to inhibit CDK2, leading to Rb dephosphorylation in hepatocarcinoma cells (Kim et al. 2000).

\section{Effects of Exogenous Ceramide Administration on p53}

Some investigators claim that ceramide can act upstream of p53, such as in Ras-induced senescence (Castro et al. 2008). However, most of these studies involve exogenous ceramide treatment and may have limited applicability for understanding temporal relationships in endogenous cellular responses. Nonetheless, exogenous $\mathrm{C}_{2}$-ceramide treatment in primary cortical neuron cultures can increase c-jun, c-fos, and p53 mRNA (Willaime et al. 2001) and increase cellular p53 in mouse fibroblasts (Yang and Duerksen-Hughes 2001). Treatment with $\mathrm{C}_{2}$-ceramide has also been shown to increase p53 and p27 in a mouse $\mathrm{B}$ cell lymphoma cell line; however, when these cells were transfected with the transcription factor Nur77, which is associated with resistance to ceramide-induced apoptosis in these cells, p53 was markedly downregulated after ceramide treatment (Bras et al. 2000), suggesting a criticality of $\mathrm{p} 53$ functions downstream of exogenous ceramide addition. Ceramide can also activate PP2A which inhibits Bcl-2 phosphorylation, leading to increased p53/Bcl-2 binding and apoptosis (Deng et al. 2009), whereas Bcl-2 overexpression can suppress $\mathrm{C}_{2}$-ceramidemediated apoptosis (Kolettas et al. 2006). Treatment of colon adenocarcinoma cells with $\mathrm{C}_{16}$-ceramide lead to differential expression of 51 proteins, one of which was Btf, which regulates p53 and other apoptosis-related proteins such as Mdm2, BAX, and pBcl-2 in these cells (Renert et al. 2009). Furthermore, treatment with $20 \mu \mathrm{M} \mathrm{C}_{8}$-ceramide has been shown to induce increased expression of $\mathrm{p} 53$ leading to cell cycle arrest of endothelial cells in the 
G1 phase (Lopez-Marure et al. 2000), and treatment with $\mathrm{C}_{2}$-ceramide has been shown to inhibit cell proliferation in WT, but not p53-deficient, tumor cells (Pruschy et al. 1999).

In contrast, $\mathrm{C}_{2}$-ceramide treatment has not been shown to change $\mathrm{p} 53$ levels while inducing PARP-mediated apoptosis in retinoblastoma cells (Vento et al. 1998). Other studies indicate that $\mathrm{p} 53$ protein was decreased after ceramide treatment in Bel7402 cells (Zhu et al. 2000), despite the occurrence of G0/G1 arrest in ceramide-treated B lymphoma Raji cells that lack TNF- $\alpha$ receptors (Kuroki et al. 1996). Furthermore, treatment of p53 WT or p53 mutant cells with exogenous ceramide led to apoptosis in both cell lines, whereas treatment with radiation only led to apoptosis in p53 WT cells, indicating that radiation-induced apoptosis is p53 dependent, and ceramide-induced apoptosis is not (Shi et al. 2001).

\section{p53 and Glycosphingolipids}

Although most of the work connecting p53 and sphingolipids has focused on ceramide, considerable evidence relates p53 and more complex members of the sphingolipid family. For instance, adenovirus-delivered WT p53 decreases the expression of glycosphingolipids, namely gangliosides GD1 and GM1b, in human glioma cells (He et al.; He et al. 2007). Interestingly, the ganglioside GM1 increases in density on the surface of neuroblastoma cells during the switch from proliferation to differentiation, and the sugar chain of this glycosphingolipid was found to be a ligand for galectin-7 (p53-induced gene 1) which exerts neuroblastoma growth control. So, in addition to p53-linked intracellular interactions with sphingolipids, galectin-7 appears to connect p53 to glycosphingolipids on the cell surface (Kopitz et al. 2003).

\section{Effects of Exogenous Glycosphingolipid Administration on p53}

As with ceramide, exogenous administration of gangliosides has revealed functions upstream of p53. GM3 treatment of colon cancer cells was shown to stimulate PTEN expression to inhibit PI3K/AKT/MDM2 survival signaling which led to the accumulation of p53 protein and increased expression of p21 as well as a p53-independent increase in p27 (Choi et al. 2006). The ganglioside GD3 which is overexpressed in some cancers, has been shown to be internalized by activated - but not resting - T cells, and it initiates a series of pro-apoptotic events that include 553 accumulation and the induction of reactive oxygen species, enhancement of Bax accumulation, increase in mitochondrial permeability, cytochrome c release, and the activation of caspase-9 (Sa et al. 2009). Interestingly, gangliosides produced by a $\mathrm{T}$ cell lymphoma were shown to increase $\mathrm{p} 53$ and induce apoptosis in bone marrow cells (Bharti and Singh 2000).

\section{p53-independent Apoptosis}

Similar to ceramide, some studies suggest an independence of p53 and glycosphingolipidinduced apoptosis. Treatment of neuroblastoma cells with fenretinide leads to accumulation of ceramide which is then metabolized to GD3, which can result in p53-independent apoptosis. This effect is enhanced by co-treatment with modulators of ceramide metabolism in various solid tumor cell lines (Maurer et al. 1999; Maurer et al. 2000; O'Donnell et al. 2002; Corazzari et al. 2005). Moreover, the chemotherapeutic topoisomerase I inhibitors of the camptothecin family have been proposed to favor ceramide signaling by disturbing sites of synthesis (Golgi) and trafficking of glucosylceramide from the Golgi to lipid droplets, leading to caspase- 3 activation and the induction of p53-independent apoptosis in colon HT29 cells (Chauvier et al. 2002). 


\section{p53 and Sphingolipid Metabolizing Enzymes}

Various enzymes involved in sphingolipid metabolism have been shown to interact with p53 (Figure 1). For instance, p53-dependent expression of acid ceramidase in glioma cells leads to a decrease in ceramide and can protect cells from gamma radiation-induced apoptosis (Hara et al. 2004). Ceramide synthase 2-null mice which are unable to produce very long chain $\left(\mathrm{C}_{22-24}\right)$ ceramides accumulate $\mathrm{C}_{16}$-ceramide and have increased $\mathrm{p} 53$ and $\mathrm{p} 21$ messages after the first two weeks of life, leading to defects in liver homeostasis (PewznerJung et al.). Interestingly, in the setting of Atm deficiency in which p53 is not notified of unrepaired DNA double-strand breaks, a ceramide synthase-mediated pathway of apoptosis prevails (Rotolo et al.).

\section{p53 and the Sphingomyelinase (SMase) Pathway}

Because sphingomyelin is the most prevalent sphingolipid in cells, serving as an important cell membrane component, several studies of p53 and the sphingomyelinase pathway of ceramide formation propose topologically separate signaling mechanisms in which cell stress induces the membrane-based sphingomyelin pathway, whereas p53-dependent apoptosis occurs secondary to DNA damage. For instance, in some tissues such as the lung and heart endothelium and the pleura and pericardium mesothelium, radiation-induced apoptosis appears to be primarily dependent on acid SMase and, for the most part, independent of p53. In contrast, thymic apoptosis appears to be highly dependent on p53 and dependent to a lesser degree on acid SMase (Santana et al. 1996). Furthermore, ceramide generated by activation of acid SMase has been shown to be involved in p53-independent Fas-induced apoptosis (Sawada et al. 2002). The SMases and p53 are also involved in ceramide formation after TNF- $\alpha$-induced caspase 8 activation which results in apoptosis. In glioma cells possessing WT $\mathrm{p} 53$, TNF- $\alpha$ stimulated ceramide formation via the activation of both neutral and acid SMases, accompanied by superoxide anion production, and induced mitochondrial depolarization and cytochrome $\mathrm{c}$ release, whereas p53-deficient cells were partially resistant to TNF- $\alpha$ and lacked superoxide anion generation and neutral SMase activation (Sawada et al. 2004). Thus p53 appears to be required for the activation of neutral, but not acid, SMase.

When fibrosarcoma cells with WT p53 were treated with neutral SMase, cell proliferation was reduced. However, neutral SMase treatment did not affect the proliferation of p53deficient tumor cells, suggesting that p53 can be important for stress-induced apoptotic signal transduction cascades generated at the plasma membrane (Pruschy et al. 1999). One report suggested that p53 may modulate ceramide generation by activation of neutral SMase through the formation of superoxide anion in response to etoposide treatment (Sawada et al. 2001). However, in another study, Akt degradation and ceramide accumulation resulting from oxidative stress-induced neutral SMase activity may be p53 independent (Martin et al. 2002). Even so, a connection between the "membrane/sphingomyelin" and "DNA damage/ p53" stress responses is evidenced by the coordinate regulation of neutral SMase and SK, because our laboratory has shown that various DNA damaging agents that induce p53 result in p53-dependent down regulation of SK1 (Taha et al. 2004). Importantly, SK isoforms and neutral SMase collaborate in their regulation of chemosensitivity by controlling ceramide formation and the downstream Akt pathway in human colon cancer cells (Nemoto et al. 2009).

\section{Connections between p53 and SK}

As mentioned above, the SK1/S1P pathway has been shown to play a role in cancer progression and in tumor chemoresistance. Whereas abundant data have established that p53 is a tumor suppressor whose loss leads to carcinogenesis—a novel finding-our laboratory 
reported that treating Molt-4 human leukemia cells with the DNA-damaging agent actinomycin D (act D) decreases SK1 (Taha et al. 2004). Because many chemotherapeutic agents can up-regulate p53 in cells via DNA damaging capacities, the requirement for p53 in act D-mediated SK1 down-regulation was investigated. Specifically, Taha and colleagues used a Molt- 4 cell system expressing either the retroviral empty vector LXSN or the vector into which was inserted the E6 gene of human papilloma virus (Taha et al. 2004). The E6 protein has been shown to target p53 to ubiquitination and subsequent proteasomal degradation (Kessis 1993; Dbaibo et al. 1998). Treatment of cells for $24 \mathrm{hr}$ with $10 \mathrm{ng} / \mathrm{ml}$ act D profoundly decreased SK1 protein in vector control cells; in contrast, cells overexpressing E6 failed to show loss of SK1 in response to act D (Taha et al. 2004). Of note, p53 was significantly induced in LXSN cells, and this was not observed in E6expressing cells. Similar to SK1 protein, SK activity was also regulated by p53, in which act D markedly decreased ( $50 \%)$ enzymatic activity in control cells but not in E6-transfected cells (Taha et al. 2004). These data strongly suggest that act D-mediated SK1 loss in Molt-4 cells depends on the accumulation of $\mathrm{p} 53$. Based on this initial observation by Taha et al., further work in our laboratory established a conserved connection between p53 and SK1 in response to genotoxic stress in various cell lines (unpublished data).

Whereas p53 has been shown to regulate SK1 (Taha et al. 2004), SK2 appears to share an important function of p53, namely induction of the cell cycle inhibitor p21 (Sankala et al. 2007; Hait et al. 2009). The finding that p53 regulates one SK isoform and the other isoform regulates one of its main effectors, suggests that SK is an important connection between the p53 and sphingolipid pathways. Interestingly, SK1 is stimulated to stabilize HIF-1 $\alpha$ in response to reactive oxygen species (Ader et al. 2008), which has been shown to antagonize the 553 homologue in C. elegans and DNA damage-induced apoptosis (Sendoel et al.). This SK1 regulated protein has also been shown to be upregulated in p53 KO tumors (Samper et al. 2009). Another possible connection between p53 and SK1 is their role in autophagy. For example, cytoplasmic p53 has been shown to inhibit the AMP-dependent kinase, a positive regulator of autophagy, and activates the mammalian target of rapamycin (mTOR), a negative regulator of autophagy (Mathew et al. 2007), SK1 has been shown to inhibit mTOR and induce autophagy (Lavieu et al. 2006). Thus, p53-dependent downregulation of SK1 could contribute to signaling for autophagy.

\section{Connection between p53 and S1P Lyase}

Downstream of SK is the terminal enzyme of sphingolipid catabolism, S1P lyase (E.C. 4.1.2.27). When S1P lyase is overexpressed in HEK293 cells, it potentiates apoptosis in response to DNA damage. This affect appeared to be independent of ceramide generation, but required p53, as well as caspase 2, p53-inducible death domain protein, and p38 MAP kinase (Oskouian et al. 2006). We found that cathepsin B or caspase-dependent degradation of SK1 can lead to decreased S1P. Thus the potentiated apoptosis observed in S1P lyaseoverexpressing cells may depend on both the decreased production and increased degradation of cytoprotective S1P.

\section{p53 and Sphingolipids in Animal Models}

$\mathrm{Hu}$ and co-workers reported that, in a mouse model of azoxymethane-induced colon cancer - whose chow was supplemented with sphingomyelin, WT ( $\mathrm{p}=0.15)$ and $\mathrm{p} 53 \mathrm{HZ}(\mathrm{p}=0.12)$ mice had a reduced but nonsignificant tumor incidence. Thus, increasing intestinal SMase activity and suppressing proliferation, the additional dietary sphingomyelin did not promote apoptosis and did not significantly protect mice (Hu et al. 2008). Long-term treatment with the marine sponge glycolipid, $\alpha$-galactosylceramide, can significantly delay sarcoma development in $\mathrm{p} 53 \mathrm{KO}$ mice; however, it did not affect lymphoma development in these mice. Effects of $\alpha$-galactosylceramide on sarcomagenesis are thought to rely on its 
activation of natural killer cells and CD8+ cytotoxic T-cells to secrete anti-angiogenic interferon gamma (Hayakawa et al. 2003). Furthermore, in a dextran sodium sulfate (DSS)induced colitis model which has been shown to lead to enhanced neoplasia in p53 KO mice (Chang et al. 2007), a COX-2 inhibitor reduced the incidence of colon cancer (Mukawa et al. 2008); likewise SK1 KO mice with no colonic COX-2 response were also protected from the development of DSS-induced colitis (Snider et al. 2009). While not directly linked, these studies suggest a connection between the p53 and sphingolipid pathways in various animal models of cancer. Moreover, they predict a complex and interwoven role of these pathways in controlling proliferation, angiogenesis, and inflammation, all of which are critically involved in carcinogenesis.

\section{Tumor Cell Senescence, p53, and Sphingolipids}

Data from our laboratory and others have suggested a link between the p53 tumor suppressor protein and changes in sphingolipids (Summarized in Figure 2). The proapoptotic sphingolipid, ceramide, has been shown to increase in a p53-dependent manner in response to genotoxic stress (Vousden KH 2002). In fact, several inducers of apoptosis have been shown to increase ceramide in cells concomitant with p53 activation (Haupt et al. 1995; Kakudo et al. 2005; Green and Kroemer 2009). Although ceramides have been reported to induce apoptosis in cells irrespective of p53 status (Chipuk et al. 2003; Chipuk et al. 2004), p53 activation may enhance the effects of ceramide (Evan G 1998; Mathew et al. 2007). Work in our laboratory suggests that treatment of Molt-4 leukemia cells with the act D results in proteolysis of SK1 in a p53-dependent manner (Taha et al. 2004). Furthermore, Oskouian et al. showed that overexpression of S1P lyase can potentiate an apoptotic response to DNA damage in a p53-dependent manner (Strano et al. 2007). These studies suggest that some enzymes controlling cellular levels of ceramide and S1P appear to act as effectors of the p53 tumor suppressor pathway.

Similar to the aforementioned studies connecting the sphingolipid and p53 pathways, the majority of studies to examine effects of chemotherapeutic agents on cancer cell responses have focused on apoptotic mechanisms. Apoptosis may be regarded as the most desired outcome and a more straightforward aspect to study (with several well-defined events such as caspase activation, cytochrome $\mathrm{c}$ release, and DNA fragmentation). However, recent studies indicate that, in addition to apoptosis, tumor cell senescence may be a crucial determinant for the in vivo response to chemotherapy (Berns 2002; Roninson 2002; Ricci and Zong 2006), thus raising the possibility that mechanisms of tumor cell senescence could be attractive therapeutic targets.

\section{Tumor Cell Senescence as a Chemotherapeutic Mechanism}

The connections between sphingolipids and p53 discussed above suggest that p53-dependent regulation of sphingolipid could also be an important component of the senescence response. Recent studies that illustrate the concept of tumor cell senescence are contributions of Lowe's group who suggest that Bcl-2 overexpression was more effective at inhibiting tumor shrinkage in mice than was the loss of p53 (Schmitt et al. 2002). However, these studies also showed that in the long-term, p53 null-tumors were more resistant to chemotherapy than Bcl-2-overexpressing tumors. These studies suggest that inhibition of apoptosis was not the sole determinant of tumor response outcomes. In fact, when these tumors were examined closely, it became evident that tumors overexpressing Bcl-2, but not those that null for $\mathrm{p} 53$, could engage a senescence pathway and thus overcome resistance to chemotherapeutic agents. In more recent studies, Lowe's group developed an elegant model in which they could conditionally regulate endogenous p53 in a p53-deficient mouse hepatocarcinoma model. They reported that with this model, reactivation of $\mathrm{p} 53$ led to tumor regression 
primarily by cellular senescence, and by triggering an innate immune response that targeted tumor cells and resulted in their clearance in vivo (Lozano; Xue et al. 2007). Mice with mutations in p53 that abrogate its apoptotic signaling but maintain its induction of p21 and senescence, protect chromosome stability and delay tumor onset compared to full knockout of p53, highlighting the importance of cell cycle arrest in p53-induced tumor suppression (Liu et al. 2004). To confirm this connection, compound mutant mice homozygous for the p53R172P mutation that lacks p21, develop tumors with almost the same survival curve as p53-null mice (Barboza et al. 2006). Furthermore, restoration of p53 functions in sarcomas from p53-null mice results in tumor regression via a senescence phenotype whereas restoration of p53 function in T-cell lymphomas lacking p53 results in apoptosis and tumor regression (Ventura et al. 2007).

In addition, ample evidence in the literature demonstrates that chemotherapeutic agents induce cancer cell senescence (Joyner et al. 2006; Probin et al. 2007). Interestingly, this program of senescence is somewhat distinct from normal cellular senescence in that it occurs rapidly (within 7 days of treatment) and does not appear to be mediated by telomere shortening but rather by activation of p53 pathways (Roninson 2002). Of note is that ceramide has been shown by our laboratory (Venable et al. 1995) and subsequently, by others (Mouton and Venable 2000; Gao et al. 2001), to induce a rapid program of cellular senescence in cells that have no telomerase activity, indicating that it can engage a nontelomere-dependent program of cellular senescence. Moreover, we and others have shown that ceramide is significantly increased in cellular senescence (Venable et al. 1995; Venable et al. 2006). Given the importance of the senescence response for the tumor-suppressive function of $\mathrm{p} 53$, the involvement of ceramide in cellular senescence provides another putative intersection point between the p53 and sphingolipid pathways.

In fact, data from our laboratory further suggests that downregulation of SK1 by p53 in response to DNA damage could result in ceramide-induced senescence. As previously mentioned, act D was shown to signal for p53-dependent degradation of SK1 (Taha et al. 2004). Other stress-inducing agents such as etoposide and TNF were also shown to induce proteolytic degradation of SK1, leading to alterations in sphingolipid levels (Taha et al. 2005; Taha TA 2004). Importantly, knockdown of SK1 results in a 2-fold increase in the upstream signaling molecule ceramide and induces G1 arrest in MCF-7 breast cancer cells (Taha et al. 2006). Collectively, these results suggest that basal SK1 may potentially regulate growth-inhibiting lipid ceramide, and that p53-dependent degradation of SK1 may shift the sphingolipid balance toward growth inhibition and cell senescence.

\section{Summary}

Both the sphingolipid and p53 pathways are important regulators-and apparent collaborators-of cell-fate decisions. Whereas some investigations have suggested that ceramide and more complex sphingolipids function upstream of p53 or in a p53-independent manner, other studies propose that p53-dependent alterations in these sphingolipids can also contribute to apoptosis. Further studies focusing on sphingolipid metabolizing enzymes have revealed that they function similarly both upstream and downstream of p53 activation.

However, whereas various components of the sphingolipid and p53 pathways may simultaneously function to elicit apoptosis and/or growth inhibition, SMase and SK1 may undergo explicit regulation by $\mathrm{p} 53$ that could contribute to ceramide-induced senescence in cells. Thus, we propose that regulation of bioactive sphingolipid signaling molecules could be of therapeutic benefit in the treatment of p53-dependent cancers. 


\section{Acknowledgments}

VA Merit, NIH/NIA R01 016583, NIH/NIGMS R01 062887, NIH/COBRE P20 RR176771, and NIH/NCI PO1 CA097132 to (LMO) and NRSA F30ES017379 to (LAHS).

\section{References}

Ader I, Brizuela L, Bouquerel P, Malavaud B, Cuvillier O. Sphingosine kinase 1: a new modulator of hypoxia inducible factor 1alpha during hypoxia in human cancer cells. Cancer Res. 2008; 68:863542. [PubMed: 18922940]

Barboza JA, Liu G, Ju Z, El-Naggar AK, Lozano G. p21 delays tumor onset by preservation of chromosomal stability. Proc Natl Acad Sci U S A. 2006; 103:19842-7. [PubMed: 17170138]

Bates S, Phillips AC, Vousden KH. Cell cycle arrest and DNA endoreduplication following p21Waf1/ Cip1 expression. Oncogene. 1998; 17:1691-703. RK. [PubMed: 9796698]

Bergelin N, Blom T, Heikkila J, Lof C, Alam C, Balthasar S, Slotte JP, Hinkkanen A, Tornquist K. Sphingosine kinase as an oncogene: autocrine sphingosine 1-phosphate modulates ML-1 thyroid carcinoma cell migration by a mechanism dependent on protein kinase C-alpha and ERK1/2. Endocrinology. 2009; 150:2055-63. [PubMed: 19116345]

Berns A. Senescence: a companion in chemotherapy? Cancer Cell. 2002; 1:309-11. [PubMed: 12086843]

Bharti AC, Singh SM. Induction of apoptosis in bone marrow cells by gangliosides produced by a T cell lymphoma. Immunol Lett. 2000; 72:39-48. [PubMed: 10789680]

Bras A, Albar JP, Leonardo E, de Buitrago GG, Martinez AC. Ceramide-induced cell death is independent of the Fas/Fas ligand pathway and is prevented by Nur77 overexpression in A20 B cells. Cell Death Differ. 2000; 7:262-71. [PubMed: 10745271]

Castro ME, Ferrer I, Cascon A, Guijarro MV, Lleonart M, Ramon y, Cajal S, Leal JF, Robledo M, Carnero A. PPP1CA contributes to the senescence program induced by oncogenic Ras. Carcinogenesis. 2008; 29:491-9. [PubMed: 18204081]

Chang WC, Coudry RA, Clapper ML, Zhang X, Williams KL, Spittle CS, Li T, Cooper HS. Loss of p53 enhances the induction of colitis-associated neoplasia by dextran sulfate sodium. Carcinogenesis. 2007; 28:2375-81. [PubMed: 17557903]

Chauvier D, Morjani H, Manfait M. Ceramide involvement in homocamptothecin- and camptothecininduced cytotoxicity and apoptosis in colon HT29 cells. Int J Oncol. 2002; 20:855-63. [PubMed: 11894136]

Chipuk JE, Kuwana T, Bouchier-Hayes L, Droin NM, Newmeyer DD, Schuler M, Green DR. Direct activation of Bax by 553 mediates mitochondrial membrane permeabilization and apoptosis. Science. 2004; 303:1010-4. [PubMed: 14963330]

Chipuk JE, Maurer U, Green DR, Schuler M. Pharmacologic activation of p53 elicits Bax-dependent apoptosis in the absence of transcription. Cancer Cell. 2003; 4:371-81. [PubMed: 14667504]

Choi HJ, Chung TW, Kang SK, Lee YC, Ko JH, Kim JG, Kim CH. Ganglioside GM3 modulates tumor suppressor PTEN-mediated cell cycle progression--transcriptional induction of p21(WAF1) and p27(kip1) by inhibition of PI-3K/AKT pathway. Glycobiology. 2006; 16:573-83. [PubMed: 16574813]

Corazzari M, Lovat PE, Oliverio S, Di Sano F, Donnorso RP, Redfern CP, Piacentini M. Fenretinide: a p53-independent way to kill cancer cells. Biochem Biophys Res Commun. 2005; 331:810-5. [PubMed: 15865936]

Dbaibo GS, Pushkareva MY, Rachid RA, Alter N, Smyth MJ, Obeid LM, Hannun YA. p53-dependent ceramide response to genotoxic stress. J Clin Invest. 1998; 102:329-39. [PubMed: 9664074]

Deng X, Gao F, May WS. Protein phosphatase 2A inactivates Bcl2's antiapoptotic function by dephosphorylation and up-regulation of Bcl2-p53 binding. Blood. 2009; 113:422-8. [PubMed: 18845789]

Donehower LA, Harvey M, Slagle BL, McArthur MJ, Montgomery CA Jr. Butel JS, Bradley A. Mice deficient for p53 are developmentally normal but susceptible to spontaneous tumours. Nature. 1992; 356:215-21. [PubMed: 1552940] 
El-Assaad W, Kozhaya L, Araysi S, Panjarian S, Bitar FF, Baz E, El-Sabban ME, Dbaibo GS. Ceramide and glutathione define two independently regulated pathways of cell death initiated by p53 in Molt-4 leukaemia cells. Biochem J. 2003; 376:725-32. [PubMed: 12967322]

Evan G. A matter of life and cell death. Science. 1998; 281:1317-1322. LT. [PubMed: 9721090]

Gao YF, Chen X, Su XQ, Zhai ZH. Rapid induction of senescence-like changes in human umbilic vein endothelial cells(HUVECs) by C6 ceramide. Shi Yan Sheng Wu Xue Bao. 2001; 34:333-5. [PubMed: 12549215]

Green DR, Kroemer G. Cytoplasmic functions of the tumour suppressor p53. Nature. 2009; 458:112730. [PubMed: 19407794]

Hait NC, Allegood J, Maceyka M, Strub GM, Harikumar KB, Singh SK, Luo C, Marmorstein R, Kordula T, Milstien S, Spiegel S. Regulation of histone acetylation in the nucleus by sphingosine-1-phosphate. Science. 2009; 325:1254-7. [PubMed: 19729656]

Hara S, Nakashima S, Kiyono T, Sawada M, Yoshimura S, Iwama T, Banno Y, Shinoda J, Sakai N. p53-Independent ceramide formation in human glioma cells during gamma-radiation-induced apoptosis. Cell Death Differ. 2004; 11:853-61. [PubMed: 15088070]

Haupt Y, Rowan S, Shaulian E, Vousden KH, Oren M. Induction of apoptosis in HeLa cells by transactivation-deficient p53. Genes Dev. 1995; 9:2170-83. [PubMed: 7657168]

Hayakawa Y, Rovero S, Forni G, Smyth MJ. Alpha-galactosylceramide (KRN7000) suppression of chemical- and oncogene-dependent carcinogenesis. Proc Natl Acad Sci U S A. 2003; 100:9464-9. [PubMed: 12867593]

He H, Conrad CA, Nilsson CL, Ji Y, Schaub TM, Marshall AG, Emmett MR. Method for lipidomic analysis: p53 expression modulation of sulfatide, ganglioside, and phospholipid composition of U87 MG glioblastoma cells. Anal Chem. 2007; 79:8423-30. [PubMed: 17929901]

He H, Nilsson CL, Emmett MR, Ji Y, Marshall AG, Kroes RA, Moskal JR, Colman H, Lang FF, Conrad CA. Polar lipid remodeling and increased sulfatide expression are associated with the glioma therapeutic candidates, wild type p53 elevation and the topoisomerase- 1 inhibitor, irinotecan. Glycoconj J. 27:27-38. [PubMed: 19557511]

Hu Y, Le Leu RK, Belobrajdic D, Young GP. The potential of sphingomyelin as a chemopreventive agent in AOM-induced colon cancer model: wild-type and p53+/- mice. Mol Nutr Food Res. 2008; 52:558-66. [PubMed: 18324704]

Jacks T, Remington L, Williams BO, Schmitt EM, Halachmi S, Bronson RT, Weinberg RA. Tumor spectrum analysis in p53-mutant mice. Current Biology. 1994; 4:1-7. [PubMed: 7922305]

Joyner DE, Bastar JD, Randall RL. Doxorubicin induces cell senescence preferentially over apoptosis in the FU-SY-1 synovial sarcoma cell line. J Orthop Res. 2006; 24:1163-9. [PubMed: 16705698]

Kakudo Y, Shibata H, Otsuka K, Kato S, Ishioka C. Lack of correlation between p53-dependent transcriptional activity and the ability to induce apoptosis among 179 mutant p53s. Cancer Res. 2005; 65:2108-14. [PubMed: 15781620]

Kessis TD, Slebos RJ, Nelson WG, Kastan MB, Plunkett BS, Han SM, Lorincz AT, Cho KR. Hedrick L. Human papillomavirus 16 E6 expression disrupts the p53-mediated cellular response to DNA damage. Proc Natl Acad Sci U S A. 1993; 90:3988-3992. [PubMed: 8387205]

Kim E, Deppert W. Interactions of mutant p53 with DNA: guilt by association. Oncogene. 2007; 26:2185-90. [PubMed: 17401427]

Kim SS, Chae HS, Bach JH, Lee MW, Kim KY, Lee WB, Jung YM, Bonventre JV, Suh YH. P53 mediates ceramide-induced apoptosis in SKN-SH cells. Oncogene. 2002; 21:2020-8. [PubMed: 11960374]

Kim WH, Kang KH, Kim MY, Choi KH. Induction of p53-independent p21 during ceramide-induced G1 arrest in human hepatocarcinoma cells. Biochem Cell Biol. 2000; 78:127-35. [PubMed: 10874474]

Kolettas E, Skoufos I, Kontargiris E, Markopoulou S, Tzavaras T, Gonos ES. Bcl-2 but not clusterin/ apolipoprotein $\mathrm{J}$ protected human diploid fibroblasts and immortalized keratinocytes from ceramide-induced apoptosis: role of p53 in the ceramide response. Arch Biochem Biophys. 2006; 445:184-95. [PubMed: 16297852]

Kopitz J, Andre S, von Reitzenstein C, Versluis K, Kaltner H, Pieters RJ, Wasano K, Kuwabara I, Liu FT, Cantz M, Heck AJ, Gabius HJ. Homodimeric galectin-7 (p53-induced gene 1) is a negative 
growth regulator for human neuroblastoma cells. Oncogene. 2003; 22:6277-88. [PubMed: 13679866]

Kuroki J, Hirokawa M, Kitabayashi A, Lee M, Horiuchi T, Kawabata Y, Miura AB. Cell-permeable ceramide inhibits the growth of B lymphoma Raji cells lacking TNF-alpha-receptors by inducing G0/G1 arrest but not apoptosis: a new model for dissecting cell-cycle arrest and apoptosis. Leukemia. 1996; 10:1950-8. [PubMed: 8946936]

Lavieu G, Scarlatti F, Sala G, Carpentier S, Levade T, Ghidoni R, Botti J, Codogno P. Regulation of autophagy by sphingosine kinase 1 and its role in cell survival during nutrient starvation. J Biol Chem. 2006; 281:8518-27. [PubMed: 16415355]

Liu G, Parant JM, Lang G, Chau P, Chavez-Reyes A, El-Naggar AK, Multani A, Chang S, Lozano G. Chromosome stability, in the absence of apoptosis, is critical for suppression of tumorigenesis in Trp53 mutant mice. Nat Genet. 2004; 36:63-8. [PubMed: 14702042]

Lopez-Marure R, Ventura JL, Sanchez L, Montano LF, Zentella A. Ceramide mimics tumour necrosis factor-alpha in the induction of cell cycle arrest in endothelial cells. Induction of the tumour suppressor p53 with decrease in retinoblastoma/protein levels. Eur J Biochem. 2000; 267:4325-33. [PubMed: 10880954]

Lozano G. Mouse models of p53 functions. Cold Spring Harb Perspect Biol. 2:a001115. [PubMed: 20452944]

Martin D, Salinas M, Fujita N, Tsuruo T, Cuadrado A. Ceramide and reactive oxygen species generated by $\mathrm{H} 2 \mathrm{O} 2$ induce caspase-3-independent degradation of Akt/protein kinase B. J Biol Chem. 2002; 277:42943-52. [PubMed: 12213802]

Mathew R, Karantza-Wadsworth V, White E. Role of autophagy in cancer. Nat Rev Cancer. 2007; 7:961-7. [PubMed: 17972889]

Maurer BJ, Melton L, Billups C, Cabot MC, Reynolds CP. Synergistic cytotoxicity in solid tumor cell lines between $\mathrm{N}$-(4-hydroxyphenyl)retinamide and modulators of ceramide metabolism. J Natl Cancer Inst. 2000; 92:1897-909. [PubMed: 11106681]

Maurer BJ, Metelitsa LS, Seeger RC, Cabot MC, Reynolds CP. Increase of ceramide and induction of mixed apoptosis/necrosis by $\mathrm{N}$-(4-hydroxyphenyl)- retinamide in neuroblastoma cell lines. J Natl Cancer Inst. 1999; 91:1138-46. [PubMed: 10393722]

Mouton RE, Venable ME. Ceramide induces expression of the senescence histochemical marker, betagalactosidase, in human fibroblasts. Mech Ageing Dev. 2000; 113:169-81. [PubMed: 10714936]

Mukawa K, Fujii S, Tominaga K, Yoshitake N, Abe A, Kono T, Sekikawa A, Fukui H, Ichikawa K, Tomita S, Imura J, Ono Y, Shinoda M, Hiraishi H, Fujimori T. Inhibitory effects of the cyclooxygenase-2 inhibitor, etodolac, on colitis-associated tumorigenesis in $\mathrm{p} 53$-deficient mice treated with dextran sulfate sodium. Oncol Rep. 2008; 19:393-9. [PubMed: 18202786]

Nasr R, El-Sabban ME, Karam JA, Dbaibo G, Kfoury Y, Arnulf B, Lepelletier Y, Bex F, de The H, Hermine O, Bazarbachi A. Efficacy and mechanism of action of the proteasome inhibitor PS-341 in T-cell lymphomas and HTLV-I associated adult T-cell leukemia/lymphoma. Oncogene. 2005; 24:419-30. [PubMed: 15543232]

Nemoto S, Nakamura M, Osawa Y, Kono S, Itoh Y, Okano Y, Murate T, Hara A, Ueda H, Nozawa Y, Banno Y. Sphingosine kinase isoforms regulate oxaliplatin sensitivity of human colon cancer cells through ceramide accumulation and Akt activation. J Biol Chem. 2009; 284:10422-32. [PubMed: 19240026]

O’Donnell PH, Guo WX, Reynolds CP, Maurer BJ. N-(4-hydroxyphenyl)retinamide increases ceramide and is cytotoxic to acute lymphoblastic leukemia cell lines, but not to non-malignant lymphocytes. Leukemia. 2002; 16:902-10. [PubMed: 11986953]

Oskouian B, Sooriyakumaran P, Borowsky AD, Crans A, Dillard-Telm L, Tam YY, Bandhuvula P, Saba JD. Sphingosine-1-phosphate lyase potentiates apoptosis via p53- and p38-dependent pathways and is down-regulated in colon cancer. Proc Natl Acad Sci U S A. 2006; 103:17384-9. [PubMed: 17090686]

Panjarian S, Kozhaya L, Arayssi S, Yehia M, Bielawski J, Bielawska A, Usta J, Hannun YA, Obeid LM, Dbaibo GS. De novo N-palmitoylsphingosine synthesis is the major biochemical mechanism of ceramide accumulation following p53 up-regulation. Prostaglandins Other Lipid Mediat. 2008; 86:41-8. [PubMed: 18400537] 
Pewzner-Jung Y, Brenner O, Braun S, Laviad EL, Ben-Dor S, Feldmesser E, Horn-Saban S, AmannZalcenstein D, Raanan C, Berkutzki T, Erez-Roman R, Ben-David O, Levy M, Holzman D, Park H, Nyska A, Merrill AH Jr. Futerman AH. A critical role for ceramide synthase 2 in liver homeostasis: II. insights into molecular changes leading to hepatopathy. J Biol Chem. 285:1091123. [PubMed: 20110366]

Pitson SM, Xia P, Leclercq TM, Moretti PA, Zebol JR, Lynn HE, Wattenberg BW, Vadas MA. Phosphorylation-dependent translocation of sphingosine kinase to the plasma membrane drives its oncogenic signalling. J Exp Med. 2005; 201:49-54. [PubMed: 15623571]

Probin V, Wang Y, Zhou D. Busulfan-induced senescence is dependent on ROS production upstream of the MAPK pathway. Free Radic Biol Med. 2007; 42:1858-65. [PubMed: 17512465]

Pruschy M, Resch H, Shi YQ, Aalame N, Glanzmann C, Bodis S. Ceramide triggers p53-dependent apoptosis in genetically defined fibrosarcoma tumour cells. Br J Cancer. 1999; 80:693-8. [PubMed: 10360645]

Renert AF, Leprince P, Dieu M, Renaut J, Raes M, Bours V, Chapelle JP, Piette J, Merville MP, Fillet $\mathrm{M}$. The proapoptotic C16-ceramide-dependent pathway requires the death-promoting factor Btf in colon adenocarcinoma cells. J Proteome Res. 2009; 8:4810-22. [PubMed: 19705920]

Ricci MS, Zong WX. Chemotherapeutic approaches for targeting cell death pathways. Oncologist. 2006; 11:342-57. [PubMed: 16614230]

Roninson IB. Tumor senescence as a determinant of drug response in vivo. Drug Resist Updat. 2002; 5:204-8. [PubMed: 12450785]

Rotolo JA, Mesicek J, Maj J, Truman JP, Haimovitz-Friedman A, Kolesnick R, Fuks Z. Regulation of ceramide synthase-mediated crypt epithelium apoptosis by DNA damage repair enzymes. Cancer Res. 70:957-67. [PubMed: 20086180]

Sa G, Das T, Moon C, Hilston CM, Rayman PA, Rini BI, Tannenbaum CS, Finke JH. GD3, an overexpressed tumor-derived ganglioside, mediates the apoptosis of activated but not resting $\mathrm{T}$ cells. Cancer Res. 2009; 69:3095-104. [PubMed: 19276353]

Samper E, Morgado L, Estrada JC, Bernad A, Hubbard A, Cadenas S, Melov S. Increase in mitochondrial biogenesis, oxidative stress, and glycolysis in murine lymphomas. Free Radic Biol Med. 2009; 46:387-96. [PubMed: 19038329]

Sankala HM, Hait NC, Paugh SW, Shida D, Lepine S, Elmore LW, Dent P, Milstien S, Spiegel S. Involvement of sphingosine kinase 2 in $\mathrm{p} 53$-independent induction of $\mathrm{p} 21$ by the chemotherapeutic drug doxorubicin. Cancer Res. 2007; 67:10466-74. [PubMed: 17974990]

Santana P, Pena LA, Haimovitz-Friedman A, Martin S, Green D, McLoughlin M, Cordon-Cardo C, Schuchman EH, Fuks Z, Kolesnick R. Acid sphingomyelinase-deficient human lymphoblasts and mice are defective in radiation-induced apoptosis. Cell. 1996; 86:189-99. [PubMed: 8706124]

Sawada M, Kiyono T, Nakashima S, Shinoda J, Naganawa T, Hara S, Iwama T, Sakai N. Molecular mechanisms of TNF-alpha-induced ceramide formation in human glioma cells: P53-mediated oxidant stress-dependent and -independent pathways. Cell Death Differ. 2004; 11:997-1008. [PubMed: 15131591]

Sawada M, Nakashima S, Kiyono T, Nakagawa M, Yamada J, Yamakawa H, Banno Y, Shinoda J, Nishimura Y, Nozawa Y, Sakai N. p53 regulates ceramide formation by neutral sphingomyelinase through reactive oxygen species in human glioma cells. Oncogene. 2001; 20:1368-78. [PubMed: 11313880]

Sawada M, Nakashima S, Kiyono T, Yamada J, Hara S, Nakagawa M, Shinoda J, Sakai N. Acid sphingomyelinase activation requires caspase- 8 but not $\mathrm{p} 53$ nor reactive oxygen species during Fas-induced apoptosis in human glioma cells. Exp Cell Res. 2002; 273:157-68. [PubMed: $11822871]$

Schmitt CA, Fridman JS, Yang M, Lee S, Baranov E, Hoffman RM, Lowe SW. A senescence program controlled by p53 and p16INK4a contributes to the outcome of cancer therapy. Cell. 2002; 109:335-46. [PubMed: 12015983]

Sendoel A, Kohler I, Fellmann C, Lowe SW, Hengartner MO. HIF-1 antagonizes p53-mediated apoptosis through a secreted neuronal tyrosinase. Nature. 465:577-83. [PubMed: 20520707] 
Shi YQ, Wuergler FE, Blattmann H, Crompton NE. Distinct apoptotic phenotypes induced by radiation and ceramide in both p53-wild-type and p53-mutated lymphoblastoid cells. Radiat Environ Biophys. 2001; 40:301-8. [PubMed: 11820739]

Snider AJ, Kawamori T, Bradshaw SG, Orr KA, Gilkeson GS, Hannun YA, Obeid LM. A role for sphingosine kinase 1 in dextran sulfate sodium-induced colitis. Faseb J. 2009; 23:143-52. [PubMed: 18815359]

Soussi T. p53 alterations in human cancer: more questions than answers. Oncogene. 2007; 26:21452156. [PubMed: 17401423]

Strano S, Dell'Orso S, Di Agostino S, Fontemaggi G, Sacchi A, Blandino G. Mutant p53: an oncogenic transcription factor. Oncogene. 2007; 26:2212-9. [PubMed: 17401430]

Taha TA, Kitatani K, Bielawski J, Cho W, Hannun YA, Obeid LM. Tumor necrosis factor induces the loss of sphingosine kinase-1 by a cathepsin B-dependent mechanism. J Biol Chem. 2005; 280:17196-202. [PubMed: 15710602]

Taha TA, Kitatani K, El-Alwani M, Bielawski J, Hannun YA, Obeid LM. Loss of sphingosine kinase-1 activates the intrinsic pathway of programmed cell death: modulation of sphingolipid levels and the induction of apoptosis. Faseb J. 2006; 20:482-4. [PubMed: 16507765]

Taha TA, Osta W, Kozhaya L, Bielawski J, Johnson KR, Gillanders WE, Dbaibo GS, Hannun YA, Obeid LM. Down-regulation of sphingosine kinase-1 by DNA damage: dependence on proteases and p53. J Biol Chem. 2004; 279:20546-54. [PubMed: 14988393]

Taha TA, Kozhaya L, Bielawski J, Johnson KR, Gillanders WE, Dbaibo GS, Hannun YA, Obeid LM. Down-regulation of sphingosine kinase-1 by DNA damage: dependence on proteases and $\mathrm{p} 53$. $\mathrm{J}$ Biol Chem. 2004; 279:20546-20554. OW. [PubMed: 14988393]

Vadas M, Xia P, McCaughan G, Gamble J. The role of sphingosine kinase 1 in cancer: oncogene or non-oncogene addiction? Biochim Biophys Acta. 2008; 1781:442-7. [PubMed: 18638570]

Venable ME, Lee JY, Smyth MJ, Bielawska A, Obeid LM. Role of ceramide in cellular senescence. J.Biol.Chem. 1995; 270:30701-30708. [PubMed: 8530509]

Venable ME, Webb-Froehlich LM, Sloan EF, Thomley JE. Shift in sphingolipid metabolism leads to an accumulation of ceramide in senescence. Mech Ageing Dev. 2006; 127:473-80. [PubMed: 16499950]

Vento R, Giuliano M, Lauricella M, Carabillo M, Di Liberto D, Tesoriere G. Induction of programmed cell death in human retinoblastoma Y79 cells by C2-ceramide. Mol Cell Biochem. 1998; 185:715. [PubMed: 9746206]

Ventura A, Kirsch DG, McLaughlin ME, Tuveson DA, Grimm J, Lintault L, Newman J, Reczek EE, Weissleder R, Jacks T. Restoration of p53 function leads to tumour regression in vivo. Nature. 2007; 445:661-5. [PubMed: 17251932]

Villani MG, Appierto V, Cavadini E, Bettiga A, Prinetti A, Clagett-Dame M, Curley RW, Formelli F. 4-oxo-fenretinide, a recently identified fenretinide metabolite, induces marked G2-M cell cycle arrest and apoptosis in fenretinide-sensitive and fenretinide-resistant cell lines. Cancer Res. 2006; 66:3238-47. [PubMed: 16540676]

Vogelstein B, Levine AJ. Surfing the p53 network. Nature. 2000; 408:307-310. LD. [PubMed: 11099028]

Vousden KH. Live or let die: the cell's response to p53. Nature Reviews Cancer. 2002:594-604. LX.

Weisz L, Rotter V. Transcription regulation by mutant p53. Oncogene. 2007; 26:2202-2211. OM. [PubMed: 17401429]

Weisz L, Oren M, Rotter V. Transcription regulation by mutant p53. Oncogene. 2007; 26:2202-11. [PubMed: 17401429]

Willaime S, Vanhoutte P, Caboche J, Lemaigre-Dubreuil Y, Mariani J, Brugg B. Ceramide-induced apoptosis in cortical neurons is mediated by an increase in $\mathrm{p} 38$ phosphorylation and not by the decrease in ERK phosphorylation. Eur J Neurosci. 2001; 13:2037-46. [PubMed: 11422444]

Xia P, Gamble JR, Wang L, Pitson SM, Moretti PA, Wattenberg BW, D'Andrea RJ, Vadas MA. An oncogenic role of sphingosine kinase. Curr Biol. 2000; 10:1527-30. [PubMed: 11114522]

Xue W, Zender L, Miething C, Dickins RA, Hernando E, Krizhanovsky V, Cordon-Cardo C, Lowe $\mathrm{SW}$. Senescence and tumour clearance is triggered by p53 restoration in murine liver carcinomas. Nature. 2007; 445:656-60. [PubMed: 17251933] 
Yang J, Duerksen-Hughes PJ. Activation of a p53-independent, sphingolipid-mediated cytolytic pathway in p53-negative mouse fibroblast cells treated with $\mathrm{N}$-methyl-N-nitro-N-nitrosoguanidine. J Biol Chem. 2001; 276:27129-35. [PubMed: 11369765]

Zhu XF, Zhang XS, Li ZM, Yao YQ, Xie BF, Liu ZC, Zeng YX. Apoptosis induced by ceramide in hepatocellular carcinoma Bel7402 cells. Acta Pharmacol Sin. 2000; 21:225-8. [PubMed: 11324420] 


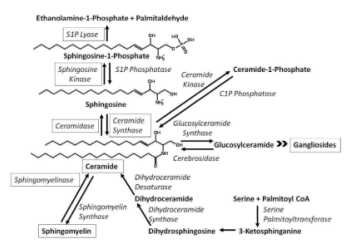

Figure 1.

Overview of sphingolipid metabolism. Boxes indicate the points of connection between the p53 pathway and sphingolipid metabolism discussed in this review. S1P: Sphingosine-1Phosphate and C1P: Ceramide-1-Phosphate. 


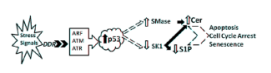

Figure 2.

Proposed points of p53-dependent regulation of the sphingolipid pathway after cell stress. DDR: DNA Damage Response, ARF: Alternate Reading Frame product, ATM: Ataxia Telangiectasia Mutated protein, ATR: Ataxia Telangiectasia and Rad3-related protein, p53: Tumor Suppressor Protein p53, SMase: Sphingomyelinase, SK1: Sphingosine Kinase 1, Cer: Ceramide, and S1P: Sphingosine-1-Phosphate. 